\title{
KECENDERUNGAN PEMILIHAN LOKASI PEMUKIMAN BERDASARKAN ANALISIS MULTIKRITERIA DI KOTA MANADO
}

\author{
Winsy Christo Deilan Weku ${ }^{1)}$ \\ ${ }^{1)}$ Program Studi Matematika FMIPA Universitas Sam Ratulangi Manado \\ Jl. Kampus Unsrat, Manado 95115 \\ Email : wincy24@yahoo.com
}

\begin{abstract}
ABSTRAK
Penelitian ini bertujuan untuk menentukan faktor-faktor dominan (kriteria) yang mempengaruhi individu dalam memilih lokasi pemukiman. Selanjutnya lokasi-lokasi pemukiman diurutkan sesuai dengan selera/kecenderungan yang ada pada responden. Untuk menjembatani berbagai kriteria yang saling berbeda dari para responden, maka dapat digunakan metode Multi Criteria Decision Making (MCDM) dengan metode yang terpilih yaitu metode Penjumlahan Terboboti/Simple Additive Weighting (SAW) dan metode Jarak Terdekat ke Titik Ideal/Technique for Order Preference by Similarity to Ideal Solution (TOPSIS), dimana kedua metode ini saling melengkapi satu sama lainnya. Dari hasil penelitian didapatkan bahwa responden secara umum, responden berpendidikan sarjana dan responden berpendapatan kelas bawah cenderung memilih lokasi pemukiman Telkom Mas sebagai pilihan utama. Berbeda halnya dengan responden berpendidikan non-sarjana dan responden berpendapatan kelas atas cenderung untuk memilih Citra Land sebagai lokasi pemukimannya.
\end{abstract}

Kata Kunci : Lokasi Pemukiman, MCDM, SAW, TOPSIS

\section{HOUSING SUITABILITY LOCATION PREFERENCE BASED ON MULTICRITERIA ANALYSIS IN MANADO}

\begin{abstract}
The purposes of this research are to determine the dominant factors from every individual to choose their district location. Furthermore, to organized the district location according the dominant factors. For the respondent with different background, it implies to their significant criteria. Decision making problems with these characteristics are basically members of Multi Criteria Decision Making (MCDM). Simple Additive Weighting (SAW) and Technique for Order Preference by Similarity to Ideal Solution (TOPSIS) methods have been developed in this study to solve this problem as comprehensive. The results of this research reveals that general respondent, higher educated respondent and lower income respondent disposed to choose Telkom Mas as their district location. Furthermore lower respondent and higher income respondent disposed to choose Citra Land as their district location.
\end{abstract}

Keywords : District Location, MCDM, SAW, TOPSIS

\section{PENDAHULUAN}

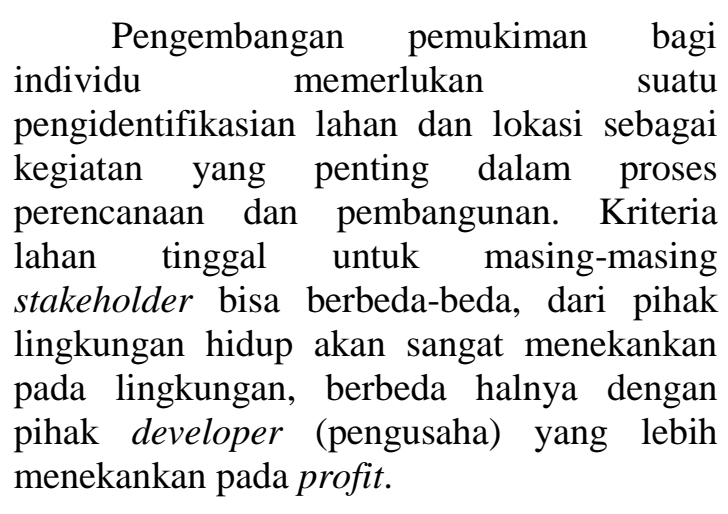

Setiap individu memiliki latar belakang sosial dan ekonomi yang berbeda-beda. Oleh karena itu, individu tersebut juga memiliki pandangan, kriteria dan pilihan yang berbedabeda untuk menentukan lahan pemukimannya. Individu yang memiliki latar belakang perekonomian yang lebih tinggi dari individu lainnya, cenderung untuk memilih daerah yang relatif lebih aman, luas, layanan/service/fasilitas yang baik, akses transportasi yang mudah, dan lain sebagainya yang memungkinkan dia untuk hidup lebih nyaman. Berbeda halnya dengan individu 
yang berpendapatan lebih rendah cenderung untuk memilih daerah yang dapat mendukung perekonomiannya tanpa memperhatikan service/pelayanan/fasilitas yang baik dan aman.

Dengan memperhatikan latar belakang tersebut, maka permasalahan yang dikaji dalam penelitian ini, yaitu bagaimana memilih lokasi pemukiman yang layak bagi setiap individu dengan memperhatikan kriteria-kriteria yang muncul berdasarkan latar belakang sosial-ekonomi individu yang berbeda. Sehingga tujuan penelitian ini adalah menganalisis faktor-faktor dominan yang mempengaruhi pengurutan lokasi pemukiman dan menetapkan urutan lokasi pemukiman berdasarkan faktor-faktor dominan di Kota Manado.

\section{Evaluasi Kesesuaian Lahan}

Menurut Malczewski dalam Kapantow (2003), setiap lahan potensial untuk pembangunan memiliki karakteristik masingmasing yang secara umum mengacu pada atribut lokasi. Atribut data termasuk informasi pada sumber daya alami, sumber daya manusia dan sumber daya buatan manusia (Kozlowski, 1986). 2 fase dalam evaluasi kesesuaian lahan ini, yaitu:

1. Fase Penyaringan, tujuan dari fase ini adalah meniadakan semua lokasi yang tidak dapat diterima untuk suatu tujuan pembangunan oleh karena adanya pertimbangan lingkungan, peraturan atau faktor-faktor lainnya.

2. Fase Evaluasi, bertujuan untuk menentukan tingkat kesesuaian setiap lokasi yang telah diterima (Kapantouw, 2003).

Beberapa hal yang harus diperhatikan untuk mengidentifikasi dan mengukur proses evaluasi kriteria antara lain: (a) identifikasi kriteria yang relevan, (b) standarisasi nilai performance, (c) pengukuran bobot nilai, (d) pengukuran skala nilai.

\section{Multikriteria Analisis}

Multiple Criteria Decision Making (MCDM), mengacu pada suatu kenyataan tentang bagaimana membuat keputusan berdasarkan banyaknya pilihan, dan biasanya mengandung kriteria yang saling bertentangan. Dalam konteks bisnis, masalah MCDM lebih kompleks dan biasanya dalam skala besar. Sebagai contoh, banyak perusahaan di Eropa menjalankan perusahaannya dengan beratus-ratus kriteria dan sub kriteria dengan mempergunakan model bisnis European Foundation for Quality Management - EFQM (Matteu, 2002).

Menurut Vincke (1986), penyelesaian masalah dalam bidang MCDM, dibedakan atas tiga jenis yaitu : (a) pemilihan masalah, (b) masalah peringkat dan (c) penyortiran data.

\section{Bentuk MCDM}

Sebuah masalah MCDM dapat digambarkan dengan menggunakan sebuah matriks keputusan. Anggap terdapat $m$ alternatif yang berhubungan dengan $n$ atribut, sehingga sebuah matriks keputusan akan berukuran $m x \quad n$ dengan masing-masing elemen $Y_{i j}$, dengan atribut ke-j dari $i$ alternatif. Data yang sudah ada dapat dibentuk ke dalam Tabel 1 berikut.

Tabel 1. Matriks Evaluasi

\begin{tabular}{|c|c|c|c|c|c|c|}
\hline & $\mathrm{K}_{1}$ & $\mathrm{~K}_{2}$ & $\mathrm{~K}_{3}$ & $\ldots$ & $\mathrm{K}_{\mathrm{j}}$ & Total Skor \\
\hline $\mathrm{P}_{1}$ & $\mathrm{y}_{11}$ & $\mathrm{y}_{12}$ & $\mathrm{y}_{12}$ & $\ldots$ & $\mathrm{y}_{1 \mathrm{j}}$ & \\
\hline $\mathrm{P}_{2}$ & $\mathrm{y}_{21}$ & $\mathrm{y}_{22}$ & $\mathrm{y}_{23}$ & $\ldots$ & $\mathrm{y}_{2 \mathrm{j}}$ & \\
\hline $\mathrm{P}_{3}$ & $\mathrm{y}_{31}$ & $\mathrm{y}_{32}$ & $\mathrm{y}_{33}$ & $\ldots$ & $\mathrm{y}_{3 \mathrm{j}}$ & \\
\hline . & . & . & . & . & . & \\
\hline • & . & . & . & $\cdot$ & · & \\
\hline . & . & . & . & . & . & \\
\hline $\mathrm{P}_{\mathrm{i}}$ & $y_{i 1}$ & $\mathrm{y}_{\mathrm{i} 2}$ & $\mathrm{y}_{\mathrm{i} 3}$ & $\ldots$ & $y_{i j}$ & \\
\hline
\end{tabular}

2. Penyelesaian MCDM, menurut sifat penyelesaiannya (Hwang dan Yoon, 1981) dibedakan menjadi (a) Penyelesaian Ideal, (b) Penyelesaian Non dominasi, (c) Penyelesaian memuaskan, (d) Penyelesaian terpilih.

3. Metode MCDM, terdiri atas dua metode MCDM, yaitu compensatory dan noncompensatory (Hwang dan Yoon, 1981).

Kedua metode ini menggunakan bentuk umum dari langkah-langkah yang dapat diberikan sebagai berikut: (Franklin dan Niemeier, 1998)

1). Menentukan tujuan yang relevan

2). Menentukan alternatif-alternatif untuk dievaluasi

3). Menentukan atribut yang relevan untuk mengevaluasi alternatif dan menentukan nilai diluar jangkauan atribut individu.

4). Merangking dan mendapatkan bobot (yang telah dinormalkan) untuk atribut kepentingan relatif. 
5). Menskor masing-masing atribut dari setiap alternatif. Setiap alternatif i dapat diasumsikan sebagai sebuah vektor deskripsi pada atribut $\mathrm{j}$ yang berbeda. $\mathrm{X}_{\mathrm{i}}=\left(\mathrm{x}_{\mathrm{i}, 1} ; \mathrm{x}_{\mathrm{i}, 2} ; \ldots ; \mathrm{x}_{\mathrm{i}, \mathrm{j}} ; \ldots ; \mathrm{x}_{\mathrm{i}, \mathrm{n}}\right)$.
6). Menghitung kegunaan multiatribut dari beragam pilihan, dengan menggunakan kedua metode skoring.

7). Menyediakan analisis pasca evaluasi dan kemudian menentukan alternatif mana yang terbaik.

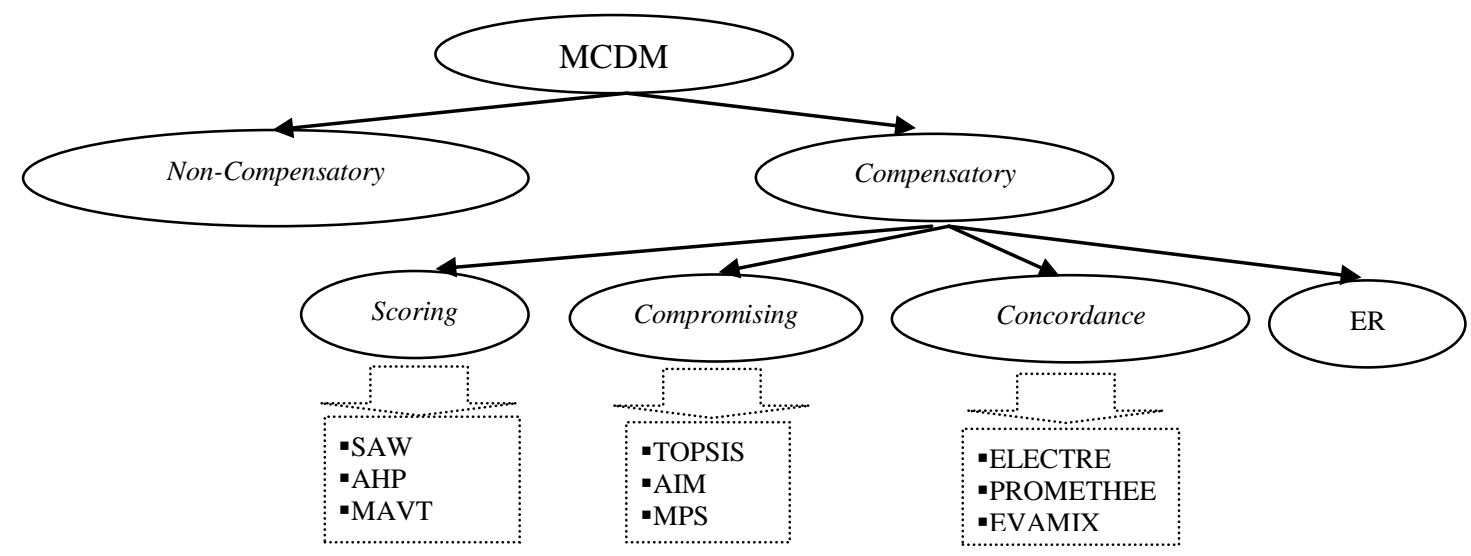

Gambar 1. Klasifikasi metode multiatribute

\section{METODOLOGI PENELITIAN}

\section{Lokasi dan Waktu Pelaksanaan}

Lokasi pemukiman yang dijadikan objek penelitian adalah CBSA Gold Estate, Green Garden, Star of Paniki, Villa Mutiara, Lembah Nyiur Kairagi Mas yang terletak di kecamatan Mapanget, Telkom Mas di kecamatan Maumbi dan Citra Land di kecamatan Pineleng. Penelitian ini dilakukan pada bulan Maret dan awal bulan April, dimana pengambilan data untuk lokasi pada awal bulan Maret dan pengambilan data untuk responden dilakukan pada akhir bulan Maret dan awal bulan April.

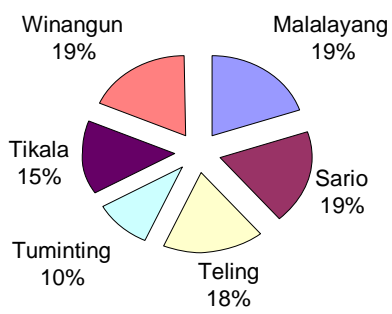

\begin{tabular}{|l|}
\hline$\square$ Malalayang \\
$\square$ Sario \\
$\square$ Teling \\
$\square$ Tuminting \\
$\square$ Tikala \\
$\square$ Winangun \\
\hline
\end{tabular}

Gambar 2. Responden Berdasarkan Wilayah Amatan

Banyaknya responden yang diambil untuk penelitian ini adalah sebanyak 80 responden yang tersebar di berbagai lokasi di kota Manado. Dengan perbandingan sebagai berikut; 16 responden di Malalayang, 15 responden di Sario (Kampus), 14 responden di Teling, 8 responden di Tuminting, 12 responden di Tikala dan 15 responden di Winangun. Sedangkan objek amatan untuk lokasi perumahan sebanyak 7 perumahan yang baru diambil secara sengaja, dengan memperhatikan kesamaan dari sisi ekonomi.

Penelitian ini membagi para responden secara umum tanpa adanya perbedaan sebanyak 80 responden, menurut pendidikan sarjana sebanyak 58 responden, non sarjana sebanyak 22 responden, kemudian tingkat pendapatan dengan mengambil median pendapatan Rp.2.675.000,- dimana responden dengan pendapatan lebih besar atau sama dengan Rp.2.675.000,- digolongkan sebagai responden kelas atas sebanyak 40 responden dan responden dengan pendapatan kurang dari Rp.2.675.000,- digolongkan sebagai responden kelas bawah sebanyak 40 responden.

\section{Analisis Data}

Data yang telah ada kemudian akan diolah dengan menggunakan bantuan komputer yang menggunakan software spread sheet Excel XP. Beberapa variabel sebagai kriteria umum yang akan diteliti untuk digunakan dalam penelitian ini adalah:

1. Kemudahan untuk mendapatkan transportasi dan layanannya.

2. Akses ke tempat hiburan.

3. Ekonomi (Harga tanah).

4. Fasilitas Layanan Umum. 



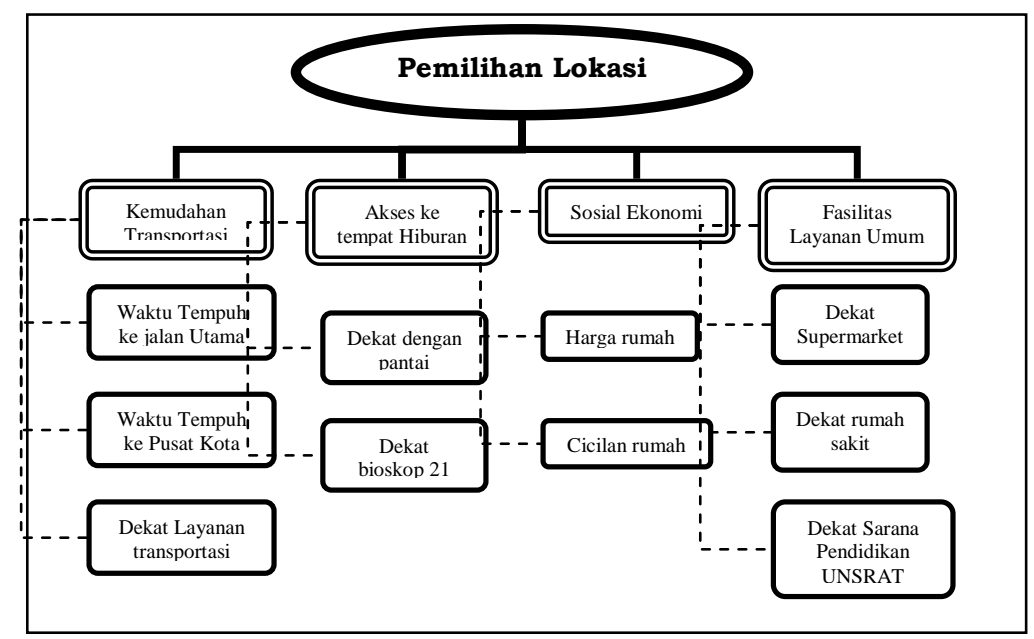

Gambar 3. Hubungan antara kriteria umum dan kriteria khusus

Dan prosedur yang dilakukan dalam penelitian ini seperti pada Gambar 4, dilakukan dua tahap, yaitu: evaluasi kesesuaian lahan pemukiman dan penentuan lokasi pemukiman yang cocok berdasarkan MCDM.

1. Evaluasi Kesesuaian Lahan Pemukiman Evaluasi kesesuaian lahan pemukiman ini dimaksudkan untuk melihat secara umum lahan yang potensial untuk ditinggali. Hal-hal yang perlu dilakukan adalah:

a). Pengambilan data. Dalam proses pengambilan data dilakukan dua kali, yaitu

1). Pengambilan data terhadap responden yang bertempat tinggal di Manado, sebanyak 80 responden dan dilakukan secara acak.

2). Pengambilan data terhadap perumahan (lokasi pemukiman), sebanyak 7 lokasi pemukiman berdasarkan kriteria khusus pula.

b). Kemudian dilakukan pencocokan antara nilai rata-rata responden untuk kriteria khusus dengan kriteria khusus lokasi pemukiman yang memenuhi syarat. Hasilnya akan didapatkan nilai kriteria $\left(\mathrm{x}_{\mathrm{ij}}\right)$ yang dapat disusun dalam sebuah tabel.

c). Dari penanganan sampel yang ada, kita memiliki 2 nilai yaitu nilai bobot $\left(\mathrm{w}_{\mathrm{ij}}\right)$ dan nilai kriteria $\left(\mathrm{x}_{\mathrm{ij}}\right)$ yang akan dihitung dengan metode MCDM.
2. Penentuan Lokasi Pemukiman yang Cocok dengan Metode MCDM

a). Metode TOPSIS

1). Menghitung standarisasi vektor normal untuk nilai kriteria $\left(\mathrm{x}_{\mathrm{ij}}\right)$, dengan rumus

$$
r_{i j}=\frac{x_{i j}}{\sqrt{\sum_{j=1}^{n} x_{i j}{ }^{2}}},
$$

dalam hal ini $j$ menyatakan 7 lokasi pemukiman, $i$ menyatakan 10 kriteria khusus yang diberikan

2). Kemudian menghitung rating bobot normal $\left(\mathrm{v}_{\mathrm{ij}}\right)$ dengan cara melakukan perkalian antara skor normal $\left(\mathrm{r}_{\mathrm{ij}}\right)$ dengan nilai bobot $\left(\mathrm{w}_{\mathrm{ij}}\right)$. Dengan rumusnya:

3). Kemudian

$$
\mathrm{v}_{\mathrm{ij}}=\mathrm{w}_{\mathrm{i}} \cdot \mathrm{r}_{\mathrm{ij}}
$$

pengidentifikasian penyelesaian positif ideal dan negatif ideal. Penyelesaian ideal positif merupakan gabungan semua kriteria terbaik yang dapat dicapai, dan dinyatakan dengan $A^{*}=\left\{\mathrm{v}_{1}{ }^{*}, \mathrm{v}_{2}{ }^{*}\right.$, $\left.\ldots, \quad \mathrm{v}_{\mathrm{i}}^{*}, \ldots, \mathrm{v}_{\mathrm{n}}{ }^{*}\right\}$, dimana $\mathrm{v}_{\mathrm{i}}{ }^{*}$ merupakan nilai terbaik untuk kriteria ke i diantara semua alternatif kriteria. Penyelesaian ideal negatif merupakan gabungan semua kriteria terjelek yang dapat dicapai, dan dinyatakan dengan $\mathrm{A}^{-}$ $=\left\{\mathrm{v}_{1}^{-}, \mathrm{v}_{2}^{-}, \ldots, \mathrm{v}_{\mathrm{i}}^{-}, \ldots, \mathrm{v}_{\mathrm{n}}^{-}\right\}$, dimana $\mathrm{v}_{\mathrm{i}}^{-}$merupakan nilai terjelek untuk kriteria ke i diantara semua alternatif kriteria. 


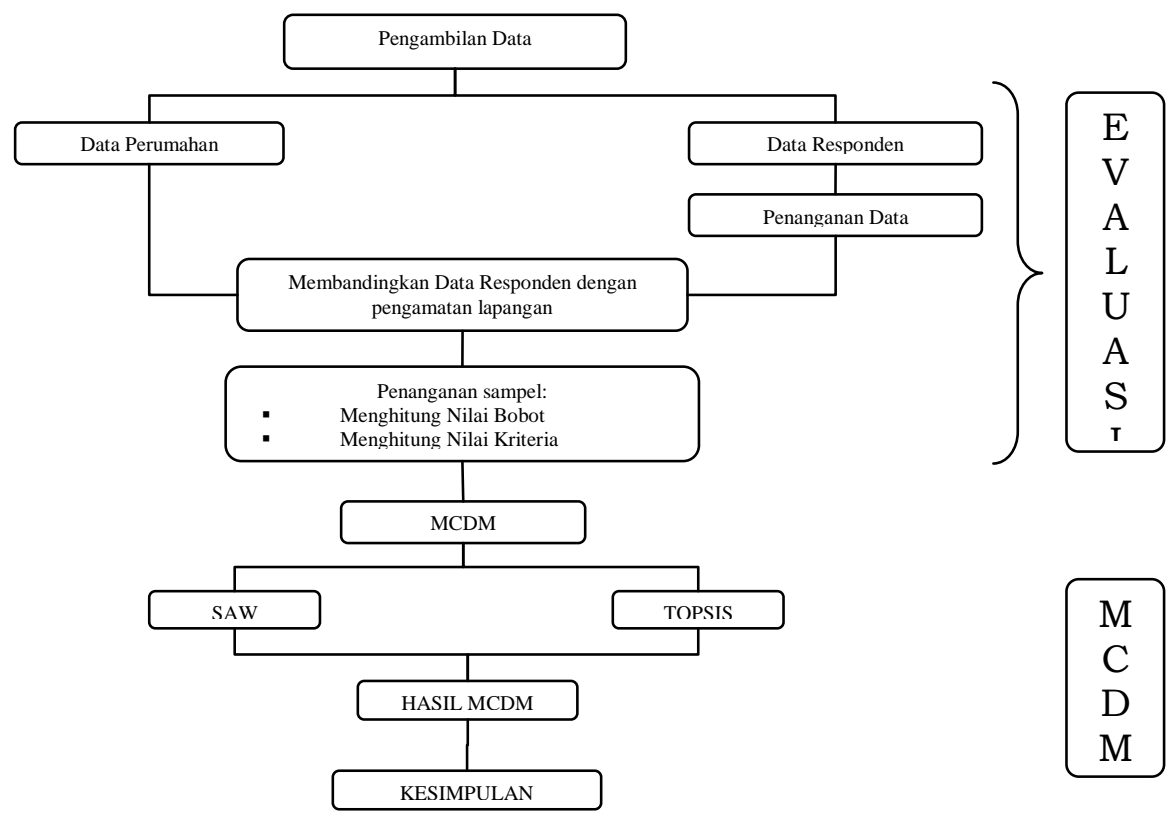

Gambar 4. Bagan Alir Pelaksanaan Penelitian

4). Menghitung pengukuran berbeda. pemisahan atau jangkauan untuk masing-masing kriteria dari penyelesaian ideal positif $A^{*}$ dan negatif $\mathrm{A}^{-}$diberikan jarak ruang dimensi $\mathrm{n}$ Euclidean, sebagai berikut:

$$
\begin{gathered}
S_{j}^{*}=\sqrt{\sum_{i=1}^{n} \mathbf{A}_{i j}-v_{i}^{{ }^{*}}{ }^{\overline{2}}} \text { dan } \\
S_{j}^{-}=\sqrt{\sum_{i=1}^{n} \mathbf{A}_{i j}-v_{i}^{-{ }^{-}}}
\end{gathered}
$$

dalam hal ini j menyatakan 7 lokasi pemukiman, i menyatakan 10 kriteria khusus

5). Menghitung kesamaan indeks untuk penyelesaian ideal positif, untuk lokasi j, akhirnya diberikan oleh

$$
C_{j}^{*}=\frac{S_{j}^{*}}{S_{j}^{*}+S_{j}^{-}},
$$

dengan $0 \leq C_{j}^{*} \leq 1$

Lokasi pemukiman yang cocok berdasarkan responden bisa didapatkan dengan cara mengurutkan nilai $\mathrm{C}$ dari yang besar ke yang paling kecil. Sehubungan dengan itu kita bisa mendapatkan kriteria-kriteria yang mendukung lokasi pemukiman tersebut. b). Metode SAW

Untuk metode SAW didapatkan dengan menjumlahkan semua nilai rating bobot normal untuk satu lokasi berdasarkan semua kriteria yang ada. Lokasi pemukiman yang cocok berdasarkan responden bisa didapatkan dengan cara mengurutkan nilai $\mathrm{C}$ dari yang besar ke yang paling kecil. Sehubungan dengan itu kita bisa mendapatkan kriteriakriteria yang mendukung lokasi pemukiman tersebut.

Kemudian dari kedua metode tersebut akan dibuat generalisasi peringkat dengan mengambil jumlah peringkat dari kedua metode tersebut (Jankowski, 1988). Hasil terkecil jumlahan rangking dari kedua metode tersebut merupakan pilihan lokasi yang terbaik, demikian juga seterusnya.

\section{HASIL DAN PEMBAHASAN}

Untuk menggunakan metode MCDM diperlukan nilai bobot dan nilai preferensi. Nilai bobot adalah nilai yang menggambarkan tingkat kepentingan relatif dari suatu kriteria terhadap kriteria lainnya. Semakin besar nilai bobot diberikan oleh responden, berarti semakin besar tingkat kepentingan dari suatu kriteria menurut responden tersebut. Nilai bobot ini harus berjumlah 1 untuk seluruh kriteria khusus yang diberikan. 
Tabel 2. Penentuan bobot responden berdasar criteria khusus

\begin{tabular}{|c|c|c|c|c|c|c|}
\hline \multirow[b]{2}{*}{ Kriteria Umum } & \multirow[b]{2}{*}{ Kriteria Khusus } & \multicolumn{5}{|c|}{ Bobot } \\
\hline & & Umum & Sarjana & $\begin{array}{l}\text { Non } \\
\text { Sarjana }\end{array}$ & $\begin{array}{c}\text { Kelas } \\
\text { Atas }\end{array}$ & $\begin{array}{l}\text { Kelas } \\
\text { Bawah }\end{array}$ \\
\hline \multirow{3}{*}{$\begin{array}{l}\text { Kemudahan Untuk } \\
\text { Mendapatkan Transportasi Dan } \\
\text { Layanannya }\end{array}$} & Waktu Tempuh Ke Jalan Utama & 0,1148 & 0,1040 & $\mathbf{0 , 1 3 1}$ & 0.108 & 0,122 \\
\hline & Waktu Tempuh Ke Pusat Kota & 0,1026 & $\mathbf{0 , 1 8 0 7}$ & 0,108 & 0.101 & 0,104 \\
\hline & $\begin{array}{l}\text { Dekat Dengan Layanan } \\
\text { Transportasi }\end{array}$ & 0,1169 & 0,1160 & 0,120 & 0.115 & 0,118 \\
\hline \multirow{2}{*}{ Akses Ke Tempat Hiburan } & Dekat Dengan Pantai & 0,0713 & 0,0668 & 0,085 & 0.073 & 0,068 \\
\hline & Waktu Tempuh Ke Bioskop 21 & 0,0944 & 0,0922 & 0,100 & 0.099 & 0,089 \\
\hline \multirow{2}{*}{ Ekonomi } & Harga Rumah & $\mathbf{0 , 1 3 3 0}$ & 0,1405 & 0,111 & 0.134 & $\mathbf{0 , 1 3 1}$ \\
\hline & Adanya Cicilan & 0,1270 & 0,1334 & 0,107 & 0.128 & 0,125 \\
\hline \multirow{3}{*}{ Fasilitas Layanan Umum } & Dekat Pusat Perbelanjaan & 0,0712 & 0,0722 & 0,068 & 0.068 & 0,073 \\
\hline & Dekat Rumah Sakit & 0,0841 & 0,0825 & 0,087 & 0.082 & 0,085 \\
\hline & $\begin{array}{l}\text { Waktu Tempuh Ke Tempat Sarana } \\
\text { Pendidikan }\end{array}$ & 0,0848 & 0,0867 & 0,079 & 0.088 & 0,081 \\
\hline Total & & 1 & 1 & 1 & 1 & 1 \\
\hline
\end{tabular}

Berdasarkan nilai kriteria yang telah ditentukan sebelumnya, maka akan diterapkan metode MCDM untuk menentukan lokasi permukiman yang cocok. Metode yang dipakai adalah TOPSIS yang nantinya akan didukung oleh metode SAW.

1. Penyelesaian Topsis

Menurut pendapat responden secara umum, maka Citra Land merupakan lokasi utama. Menurut responden berpendidikan sarjana, maka Lembah Nyiur Kairagi Mas dan Telkom Mas merupakan daerah utama pemukiman, tetapi menurut responden berpendidikan Non-Sarjana Citra Land merupakan daerah pemukiman utama. Sementara itu menurut responden kelas atas yang berpendapatan di atas median Rp.2.675.000,- Citra Land merupakan daerah pilihan utama sedangkan menurut kelas bawah yang berpendapatan di bawah median maka Telkom Mas merupakan daerah pilihan utama.

Tabel 3. Penyelesaian TOPSIS semua responden berdasar lokasi

\begin{tabular}{|l|c|c|c|c|c|}
\hline \multirow{2}{*}{ Lokasi } & \multicolumn{5}{|c|}{ Penyelesaian Topsis } \\
\cline { 2 - 6 } & Umum & Sarjana & $\begin{array}{c}\text { Non } \\
\text { Sarjana }\end{array}$ & $\begin{array}{c}\text { Kelas } \\
\text { Atas }\end{array}$ & $\begin{array}{c}\text { Kelas } \\
\text { Bawah }\end{array}$ \\
\hline CBSA & 0,3714 & 0,3483 & 0,4222 & 0,3153 & 0,3499 \\
\hline GG & 0,4991 & 0,4950 & 0,5152 & 0,4740 & 0,5575 \\
\hline SOP & 0,5896 & 0,5970 & 0,5261 & 0,5632 & 0,6287 \\
\hline VM & 0,4209 & 0,4191 & 0,4238 & 0,4179 & 0,4789 \\
\hline LNKM & 0,6141 & 0,6179 & 0,5579 & 0,5977 & 0,6432 \\
\hline TM & 0,6142 & 0,6179 & 0,5579 & 0,5981 & 0,6438 \\
\hline CL & 0,6127 & 0,6122 & 0,5778 & 0,6165 & 0,5654 \\
\hline
\end{tabular}

2. Penyelesaian SAW

Sementara itu berdasarkan SAW, menurut pendapat responden secara umum, responden berpendidikan sarjana, responden berpendidikan Non-Sarjana, responden kelas atas yang berpendapatan di atas median Rp.2.675.000,- memilih Citra Land merupakan daerah pilihan utama sedangkan menurut kelas bawah yang berpendapatan di bawah median maka Telkom Mas merupakan daerah pilihan utama.

Tabel 4. Penyelesaian SAW semua responden berdasar lokasi

\begin{tabular}{|l|c|c|c|c|c|}
\hline \multirow{2}{*}{ Lokasi } & \multicolumn{5}{|c|}{ Penyelesaian SAW } \\
\cline { 2 - 6 } & Umum & Sarjana & $\begin{array}{c}\text { Non } \\
\text { Sarjana }\end{array}$ & $\begin{array}{c}\text { Kelas } \\
\text { Atas }\end{array}$ & $\begin{array}{c}\text { Kelas } \\
\text { Bawah }\end{array}$ \\
\hline CBSA & 0,3407 & 0,3374 & 0,3534 & 0,3371 & 0,3378 \\
\hline GG & 0,3708 & 0,3703 & 0,3750 & 0,3701 & 0,3776 \\
\hline SOP & 0,3720 & 0,3740 & 0,3645 & 0,3729 & 0,3794 \\
\hline VM & 0,3562 & 0,3556 & 0,3586 & 0,3562 & 0,3610 \\
\hline LNKM & 0,3824 & 0,3835 & 0,3768 & 0,3826 & 0,3833 \\
\hline TM & 0,3829 & 0,3840 & 0,3768 & 0,3841 & 0,3850 \\
\hline CL & 0,3865 & 0,3860 & 0,3885 & 0,3907 & 0,3812 \\
\hline
\end{tabular}

3. Penyelesaian Menyeluruh Kedua Metode Sedangkan untuk jumlah ranking kedua metode, didapatkan bahwa Telkom Mas merupakan pilihan bagi responden umum, sarjana dan kelas bawah, kemudian Citra Land dipilih oleh responden non-sarjana dan kelas atas. 
Tabel 5. Total Ranking TOPSIS dan SAW semua responden berdasar lokasi

\begin{tabular}{|c|c|c|c|c|c|c|c|c|c|c|c|c|c|c|c|}
\hline \multirow{2}{*}{ Lokasi } & \multicolumn{3}{|c|}{ Ranking Umum } & \multicolumn{3}{|c|}{ Ranking Sarjana } & \multicolumn{3}{|c|}{$\begin{array}{c}\text { Ranking Non } \\
\text { Sarjana }\end{array}$} & \multicolumn{3}{|c|}{ Ranking Kelas Atas } & \multicolumn{3}{|c|}{$\begin{array}{c}\text { Ranking Kelas } \\
\text { Bawah }\end{array}$} \\
\hline & Topsis & Saw & $\begin{array}{l}\text { Jmlh } \\
\text { Rank }\end{array}$ & Topsis & Saw & $\begin{array}{l}\text { Jmlh } \\
\text { Rank }\end{array}$ & Topsis & Saw & $\begin{array}{l}\text { Jmlh } \\
\text { Rank }\end{array}$ & Topsis & Saw & $\begin{array}{l}\text { Jmlh } \\
\text { Rank }\end{array}$ & Topsis & Saw & $\begin{array}{l}\text { Jmlh } \\
\text { Rank }\end{array}$ \\
\hline CBSA & 7 & 7 & 14 & 7 & 7 & 14 & 7 & 7 & 14 & 7 & 7 & 14 & 7 & 5 & 12 \\
\hline GG & 5 & 5 & 10 & 5 & 5 & 10 & 4 & 4 & 8 & 5 & 5 & 10 & 5 & 6 & 11 \\
\hline SOP & 4 & 4 & 8 & 4 & 4 & 8 & 5 & 5 & 10 & 4 & 4 & 8 & 3 & 4 & 7 \\
\hline VM & 6 & 6 & 12 & 6 & 6 & 12 & 6 & 6 & 12 & 6 & 6 & 12 & 6 & 7 & 13 \\
\hline LNKM & 2 & 3 & 5 & 1 & 3 & 4 & 2 & 2 & 4 & 3 & 3 & 6 & 2 & 2 & 4 \\
\hline TM & 1 & 2 & 3 & 1 & 2 & 3 & 2 & 2 & 4 & 2 & 2 & 4 & 1 & 1 & 2 \\
\hline $\mathrm{CL}$ & 3 & 1 & 4 & 3 & 1 & 4 & 1 & 1 & 2 & 1 & 1 & 2 & 4 & 3 & 7 \\
\hline
\end{tabular}

\section{KESIMPULAN}

Berdasarkan hasil penelitian dan pembahasan dapat disimpulkan hal-hal sebagai berikut:

1 Kecenderungan lokasi pemukiman di kota Manado didasarkan terutama pada faktor 'harga rumah'. Hal ini ditunjukkan oleh responden umum, responden berpendapatan kelas bawah dan responden kelas atas.

2 Lokasi pemukiman yang terpilih berdasarkan responden berpendidikan sarjana, responden berpendapatan kelas bawah serta responden yang digabung adalah Telkom Mas. Sedangkan lokasi pemukiman menurut responden berpendidikan non sarjana dan responden berpendapatan kelas atas cenderung memilih Citra Land.

\section{DAFTAR PUSTAKA}

Azar, F. S., 2000, Multiattribute Decision Making: Use of Three Scoring Methods to Compare The Performance of Imaging Techniques for Breast Cancer Detection, Univ. Of Pennsylvania, Philadelphia.

Franklin, J. P.; Niemeier, D. A., 1998, The Prioritization Of Mobility Improvements Using A Multicriteria Prioritization Algorithm Final Report, University of California.
Hwang C. L. and Yoon K., 1981, Multiple Attribute Decision Making Methods and Applications, Springer-Verlag, New York.

Isard, W., 1977, Introduction to Regional Science, Prentice-Hall, Inc. Englewood Cliffs, New Jersey.

Kapantouw, G., 2003, A Spatial Decision Support System For Location Suitability Analysis For Sustainable Tourism Development - Tesis Doctoral, The University Of Queensland.

Kozlowski J. 1986, Threshold Approach In Urban, Regional, and Environmental Planning: Theory and Practice. St. Lucia, Queensland: University of Queensland Press.

Matteu, A. V., 2002, ClusDM: A Multiple Criteria Decision Making Method for Heterogeneous Data Sets - Tesi Doctoral, UNIVERSITAT POLITÈCNICA DE CATALUNYA, Departament de Llenguatges i Sistemes Informàtics.

Vincke, Ph., 1986, Analysis Of Multicriteria Decision Aid In Europe. European Journal of Operational Research, 25, 160-168. 